\title{
KNOWLEDGE OF COMMUNICATION ADAPTATION AS STABILIZATION OF PERFORMANCE ON INDUSTRIAL DISTRICT
}

\author{
Prayitno ${ }^{1 *}$, Sutrisno ${ }^{2}$ \\ * Corresponding author: \\ ${ }^{1}$ Politeknik Trisila Dharma Tegal, Indonesia, Email; Pra.yitno.py17@gmail.com \\ ${ }^{2}$ Universitas PGRI Semarang, Indonesia, Email; sutrisnommmpd@gmail.com
}

\begin{abstract}
Industrial districts face challenges after the advent of information technology (on line), which considers that places are not important but for some industry players and consumers to determine. Research aims to offer practical and implementable solutions for industry players so that their performance is at a minimum before or after moving to an industrial district. Journal research methods are used in this study with journal sources originating from reputable international journals and scopus indexed. The concept of the model of knowledge of communication adaptation is our finding. The concept model is derived from the industrial district theorem and organizational knowledge typology. Knowledge of communication adaptation is a mediating alternative between government perceptions and industry players. Concept definitions are explained in this study.
\end{abstract}

Keywords: Industrial district, typology of organizational knowledge, adaptation, communication.

\section{INTRODUCTION}

Errors in adopting the concept will have a negative impact on the practice side. Serious consideration of formation and the role of regional groups raises concerns about the acceptance of studies that are not yet complete. On the one hand, from the geographical point of view of the government, district knowledge may only be about location and related external forces such as resources, demand, competition, urban planning and infrastructure. On the other hand, from the geographic al point of view of entrepreneurs, the success of some companies seems to be related to internal factors that evolve through the interaction of member companies but without prior planning because, technological developments in geographic boundaries are considered not important anymore (Peteraf \& Shanley, 1997).

The different views of the industrial district between the government and industry players have a negative impact on the development and sustainability of the company. Industrial districts are "socio-geographical entities that are characterized by the active presence of the community and the corporate population in one region" (Becattini .1990). The government considers that if the industry is placed in one region, the city will be neat, not noisy, open new employment opportunities, increase export activities, increase new business opportunities, increase the economic growth index, increase the flow of urbanization and even distribution of population, this reason they cannot be fully accepted by employers, they consider that political, social, institutional, and non-economic factors are the reasons for the government. Studies that are not yet complete by the government such as the success of the Saxenian (Silicon) industrial zones of Silicon Valley and Route 128 in Boston, industrial estates in northeastern Italy and southern Germany (Lawson, 1999; Tall-man et al., 2004). It was made justification and coercion by the government to move the industry to be moved in one area but the government did not see 
that, in some developed countries as well as industrial estates failed to determine how to place industrial estates to improve company performance. (Arikan, Andac, T, 2009).

Companies in Indonesia, especially UMK, have long been united between the population and their place of business. This provides the advantage of not needing to have a rental, more efficient for working time and more importantly it is easy to find by consumers so that interactions between consumers and business owners occur faster. However, with the existence of government regulations Number 3 of 2014 concerning Law on Industry forced them to move to industrial district areas.

Based on the problems explained in the background, our research focuses on answering the question of how companies recover their performance after being transferred to industrial districts. In this study the concept of the model of the steps of the transfer process is explained which does not break communication with consumers so that before and after being transferred to the industrial district the performance is the same.

\section{LITERATURE REVIEW Industrial District}

The concept of industrial estates was triggered by the thinking system of Alfred Marshall (1842-1924). Which combines the Principles of Economics, Industry and Trade and Industrial Economy, then by Becattini the concept of the industrial district is enhanced by the concept of the work of Marshall (Becattini, 1962 and 1975a). Becattini defines an industrial district as "a socio-geographic entity that is characterized by the active presence of both the community of people and the corporate population in one region" (Becattini, 1990). Then, Cooke (1999) summarizes the Marshall construction and Becattini population based on three key elements of geographical proximity: subcontractor groups; available skilled workers; and fast formal and informal communication because the knowledge base is common across companies, employees, and the community.

Subcontracting can be described as a relationship between a parent company that asks another independent company that is a subcontractor to carry out all or part of its activities (Barley, 2016) . The existence of subcontractors is a weakness of the company because it is unable to provide skilled workers. Skilled workers are front-line workers who are proficient in specialized knowledge and technology, possess extraordinary practical skills, and have the competence and ability to overcome and overcome technical and operational problems (Dadush, Uri., 2014). To overcome the weaknesses of the company's skilled personnel, all stakeholders can be communicated so that subcontractors can be avoided. Communication is divided into the first two parts of formal communication and the second is informal communication.

Formal communication is official messages and news that flow through channels or routes that are officially recognized by the organization (Barley, 2016). Whereas informal communication is an informal message (related to work or related to people) that flows outside the officially designed channel (Barley, 2016). The organizational structure must provide communication in three different directions: downward, upward, and horizontal (Lunenburg $\&$ Ornstein, 2008). Communication up and up is internal to the company while horizontal communication emphasizes between companies and consumers. 


\section{Typology of Organizational Knowledge}

Matusik and Hill (1998) generalized organizational knowledge typologies from Henderson and Clark (1990) consisting of the notion of components versus architectural knowledge. Although the term originally refers to a narrow technical understanding of product development, Matusik and Hill (1998) apply more general terms to enterprise level knowledge. Stephen Tallman (2004) developed the idea of components divided into dimensions of specific knowledge and skills while architectural knowledge consisted of dimensions of application knowledge with adaptation routines. Our research focuses on architectural knowledge.

Knowledge architecture is knowledge that relates to organizations as a whole system and structure and routine to coordinate and integrate shared knowledge into patterns for productive use and to develop architectural knowledge and new components (Henderson \& Cockburn, 1994; Matusik \& Hill, 1998; McGaughey, 2002). Not only architectural knowledge is usually complex, intangible, and tacit, but also very specific in the organization and personal and holistic (Matusik \& Hill, 1998; Nelson \& Winter, 1982; Reed \& DeFillippi, 1990). Knowledge architecture involves organizational structures and systems and develops endogenously as an integral part of an organization, rather than existing independent organizations (Dierickx \& Cool, 1989). Because no two organizations have identical histories, no two organizations can have identical architectural knowledge. Corporate-specific architectural knowledge provides routine communication to consumers for adaptation to the environment that moves from one place to another (to industrial estates) by applying new knowledge.

\section{COMMUNICATION ADAPTATION KNOWLEDGE Conceptual Definition}

Knowledge of communication adaptation is information provided in writing or unwritten as a form of communication between business owners and consumers about the transfer of place of business. The importance of knowledge in generating competitive profits for individual companies (Grant, 1996). Knowledge can be obtained from previous experience and adapt to a changing environment, adaptation is the ability for all individuals at all levels to innovate and experiment without fear of "retaliation (failure)" or marginalization (Alvin and Heidi Toffler, 2008). Indeed, where organizational culture is to reward those who think innovatively, participants see the greatest success in adapting to solving the pressing problems facing organizations. The results of adaptation are communicated with all stakeholders to gain new knowledge. Weick and Browing (1986) defines communication as the process of delivering information from one as a sender to another person as a recipient. The conclusion is that knowledge of communication adaptation between the company and the consumer must be carried out to be able to continue to communicate so that there is no loss of contact even though the company has moved.

\section{Measuring Knowledge of Communication Adaptation}

The concept of communication adaptation knowledge defined above must be a measurable and observable concept. This concept is a combination of Industrial District dimensions and 
organizational knowledge typology dimensions. The industrial district dimension is divided into subcontractor groups; available skilled workers; and formal and informal communication. While the typology of organizational knowledge consists of components and architecture.

The core focus of communication adaptation knowledge is on the place (district) which processes and time for the long term, so for notification to consumers, the industrial district dimension is more dominant than the typology dimension of organizational knowledge. For this reason, the concept of knowledge of communication adaptation can be measured by several dimensions, namely; formal communication, informal communication and adaptation. Formal communication is notification that is officially carried out through official government institutions (decree to change place of business, siup, cv). Informal communication is notification to unofficial consumers (the bulletin board in the old place, leaving the symbol in the old place, installing a symbol in the place of a new industrial district) whose function is to remind consumers. Adaptation is to adjust the use of attributes, symbols, characteristics that the company has from the old place to be used in new places as a reminder to consumers.

Knowledge of communication adaptation is very important in the current era, where all consumers rely on gadgets to find the existence of a place of business, but for the majority of consumers, they are still searching manually for the existence of a place of business. To more easily explain the concept of knowledge of communication adaptation, Figure 1 provides a detailed description and explanation.

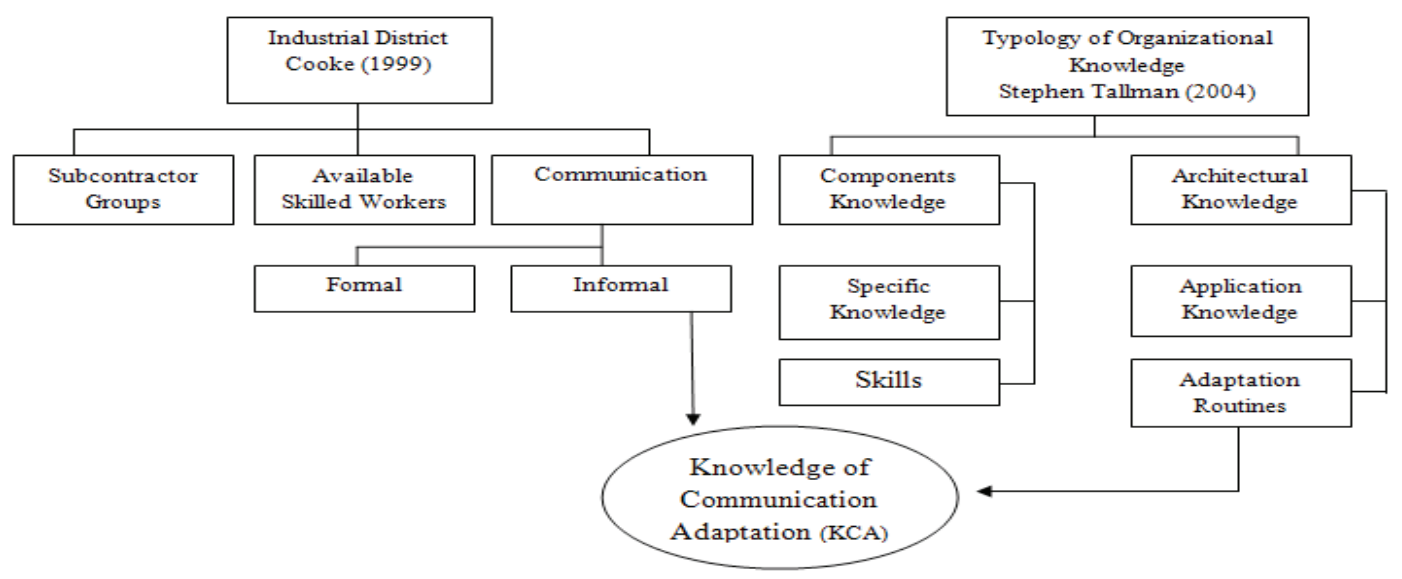

Figure 1: A Model of Developing Communication Adaptation Knowledge (KCA)

The purpose of knowledge of communication adaptation is to continue to communicate communication between producers (business owners) and consumers even though the place of business is transferred to an industrial area so that producers (business owners) do not experience losses that are too large because the place of business is moved. Efforts to stay connected with consumers can be done by giving announcements in the form of bulletin boards in old places that will be left (stickers, banners, billboards), posting announcements in new places, using symbols as characteristics that have been recognized by consumers (statues, symbols, writings, logos) and trying new experiments in a new place of business (industrial area) because intense competition in the industrial area of innovation / experimentation must be done. The conceptual model is described in Figure 2 as follows: 


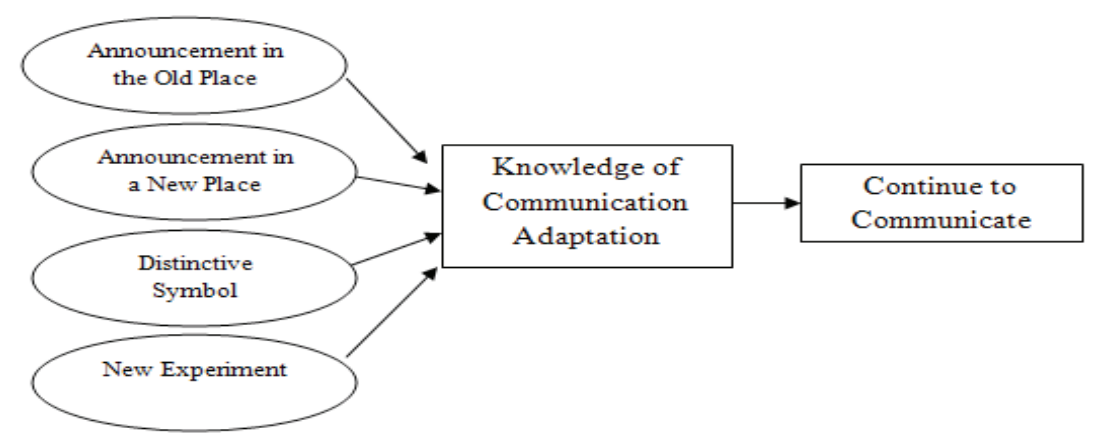

Figure.2. Conceptual Model of Knowledge of Communication Adaptation

\section{CONCLUSION}

The concept of an industrial district developed successfully on the continent of Europe then this concept was brought to Indonesia in the early 2000's. However, the development of the industrial district experienced problems caused by several problems such as; businessmen experienced a decline in profession after their efforts were transferred to industrial districts, many of which returned to their original places before being transferred to industrial districts, consumers did not know the location of new businesses, government analysis was lacking in industrial district placement. These factors prevent the development of industrial districts created by the government.

Enforcement of effective communication adaptation maintains a balance of benefits because communication between producers and consumers does not break up. Consumers can find out where the business is moving with announcements left by business owners (producers), consumers can also easily find out new business places in the industrial area by recognizing the symbolic features commonly used in the old place, intense competition in industrial district because of products that homogeneous forces producers to experiment innovatively so as not to be abandoned by consumers. Future research on how consumers' behavior shifts to other products in industrial district, how producers develop innovation with general knowledge to specific knowledge in industrial district, which dimensions of enforcement of communication adaptations are more dominant to consumer loyalty need to be proven by quantitative research using Structural Equation Model (SEM).

\section{REFERENCES}

Alfred Marshall,(1842-1924). Blackwell Publishing for the Royal Economic Society. The Economic Journal, Vol. 34, No. 135 (Sep., 1924), pp. 311-372

Arikan, (2009). Interfirm Knowledge Exchanges and The Knowledge Creation Capability of Clusters

Barley,(2016) Valuing Multiple Trajectories Of Knowledge- A Critical Review And Agenda For Knowledge Management Research 
Becattini, G. (1990), "The Marshallian Industrial District as a Socio-Economic Concept", in: Industrial Districts and Inter-firm Cooperation in Italy, Pyke, F., Becattini, G. and Sengenberger, W. (eds), Geneva, IILS.

Cooke, P. (1999). The co-operative advantage of regions. In Barnes, T.J. and Gertler, M.S. (eds). The New Industrial Geography: Regions, Regulation and Institutions. London: Routledge. 54-73.

Dadush, Uri., (2014). The Effect of Low-Skilled Labor Migration on the Host Economy. Senior Associate, Carnegie Endowment for International Peace, udadush@ceip.org.

Dierickx, I. and K. Cool. (1989). 'Asset stock accumulation and sustainability of competitive advantage', Management Science, 35, pp. 1504-1511.

Grant,R.M. (1996a). Toward a knowledge-based theory of the firm. Strategic Management Journal, 17 (Winter Special Issue),109-122.

Henderson, R. and I. Cockburn (1994). 'Scale, scope and spillovers: The determinants of research productivity in drug discovery', NBER working paper no. 4466, revised.

Heidi K. Gardner,et,al, 2012) Dynamically Integrating Knowledge in Teams: Transforming Resources into Performance

Lawson, C. (1997). 'Towards a competence theory of the region'. Cambridge, UK. ESRC Centre for Business Research Working Paper No. 81.

Lunenburg, F. C., \& Ornstein, A. O. (2008). Educational administration: Concepts and practices. Belmont, CA: Cengage/Wadsworth.

Matusik, S. and Hill, C.W.L. (1998). 'The utilization of contingent work, knowledge creation and competitive advantage'. Academy of Management Review, 23, 680-697.

Peteraf, M., \&Shanley, M.1997.Getting to know you:A theory of strategic group identity. Strategic Management Journal, 18:165-186.

Nelson, R., \& Winter, S. (1982). An evolutionary theory of economic change. Cambridge, MA: Belknap Press.

Reed, R., \& De Fillippi, R.J. (1990). Causal ambiguity, barriers to imitation, and sustainable competitive advantage. Academy of Management Review, 15,88-102.

Ronald E. McGaughey, (2002),'Benchmarking business-to-business electronic commerce”, Benchmarking: An International Journal, Vol. 9 Iss: 5 pp. 471 - 484

Tallman, S., Jenkins, M., Henry, N. and Pinch, S. (2004). 'Knowledge, clusters and competitive advantage'. Academy of Management Review, 29, 258-271.

Weick, K. E. and Browning, L. D. (1986). "Argument and narration in organizational communication," Journal of Management, ISSN 0149-2063, 12: 243-59. 